\title{
Mutagenicity studies in a tyre plant: in vitro activity of workers' urinary concentrates and raw materials
}

\author{
R CREBELLI,' A PAOLETTI, ${ }^{2}$ E FALCONE, ${ }^{1}$ G AQUILINA, ${ }^{1}$ G FABRI, ${ }^{2}$ AND A CARERE
}

From the Istituto Superiore di Sanità, ${ }^{1}$ Rome, and Istituto di Medicina del Lavoro, ${ }^{2}$ Università

Cattolica, Rome, Italy

\begin{abstract}
The possible contribution to urinary mutagenicity of occupational exposures in the rubber industry was studied by assaying the urine concentrates of 72 workmen ( 44 smokers) employed in a tyre plant. Twenty three clerks (16 smokers) engaged in the administrative department of the same factory served as presumptive unexposed controls. XAD- 2 resin concentrates of urine samples were assayed in the plate incorporation test and in the microtitre fluctuation assay with Salmonella typhimurium strains TA1535, TA98, and TA100. Furthermore, the in vitro mutagenicity of the major raw materials in use at the plant was determined in the plate incorporation assay with $S$ typhimurium strains TA1535, TA1537, TA98, and TA100. The results obtained from the urinary mutagenicity study show that smoking habits, but not occupation, were statistically significantly related to the appearance of a urinary mutagenicity that was detectable with strain TA98. A possible synergistic effect of occupation with smoking was observed among tyre builders who were also smokers. The study of the raw materials showed that three technical grade materials were weakly active as mutagens in strain TA98 in the absence (poly-p-dinitrosobenzene) or in the presence of metabolic activation (mixed diaryl-pphenylendiamines and tetramethyltiuram disulphide). The latter chemical was also weakly active in strain TA100.
\end{abstract}

Several epidemiological studies, recently reviewed by the International Agency for Research on Cancer, indicate that occupation in the rubber industry is significantly related to an increased risk of developing cancer in various organs.'

The identification of the agents responsible for the increased risk of cancer or the job categories more directly concerned with this hazard, or both, is an indispensable step towards achieving primary prevention of occupational cancer in this as well as in other workplaces. In the rubber industry, however, the identification of carcinogenic agents or processes is hindered by the technological characteristics concerned. Several hundred chemicals enter the production processes of a large rubber industry in amounts ranging from a few kilograms to tons a day. The toxicological characteristics of these chemicals are largely unknown and their study is compli-

Received 15 February 1984

Accepted 4 September 1984 cated by the use of technical grade products of low purity or of mixtures of indefinite chemical identity, or both. Furthermore, during the production of finished rubber goods these chemicals find suitable conditions for cross reactions (high temperatures, catalisers, large surfaces for reaction with atmospheric oxygen or nitrogen oxide) with the possible generation of new chemical entities with new, and unforeseen, toxicological characteristics.

A promising approach to attempt to overcome these difficulties is by the direct detection of exposure to genotoxic agents in factory workers. In this connection biological monitoring techniques, such as the study of urinary mutagenicity and the cytogenetic analysis of peripheral lymphocytes, have previously been applied to monitor the occupational exposure to genotoxic chemicals in several different workplaces, including the rubber industry. ${ }^{2-5} \mathrm{Few}$ attempts have been made, however, to correlate the results of the biological monitoring with the genotoxic characteristics of the chemicals actually 
handled by the subjects investigated or with the environmental contamination by mutagenic agents, or both.

In the present study the analysis of urinary mutagenicity in rubber workers has been carried out together with an evaluation of the in vitro activity of the major rubber chemicals in use in the same factory.

\section{Materials and methods}

\section{URINARY MUTAGENICITY STUDY}

Work environment and description of the plant

These studies were carried out in 1982 and 1983. The factory, which started production in 1964, is in an area of central Italy where the economy is largely based on agriculture. Phenyl-2-naphthylamine was eliminated from the mixes in 1969 and nitrosodiphenylamine in 1979. In 1979 wide environmental improvements were also effected in the mixing area (exhaust ventilation), in the "fume" area (exhaust ventilation and the placing of plastic sheets around the mills and along the press line), and in the talc area (wetting and ventilation). Non-asbestiform talc has always been used.

All the plants are in a single wide shed. Trolleys or conveyor belts convey materials from one department to another. In the mixing area there are many scales in series. Rubber chemicals are packed into small plastic bags and then put manually into one of the two Banbury mills of the factory, together with natural or synthetic rubber. Carbon black and oils are added automatically to the compounds. Rubber starch and solvents are prepared in a small shed outside the factory. The extruding area consists of three extruders, each provided with three mills in series. The calendering area consists of two lines for ply calendering and one for wire calendering. In the tyre building department both passenger and agricultural tyres are constructed either in traditional or semiautomatic machines. Vulcanisation occurs in six automatic lines for passenger tyres and two semiautomatic lines for agricultural tyres. Inner tubes are manufactured with a semiautomatic machine and cured in a small traditional plant. Nitrogen oxide sources such as open flames or exhaust from prop- ane or diesel powered engines are not present inside the factory. The solvents of major use in the factory are technical heptane and, in smaller amounts, isopropyl alcohol, n-hexane, and ethyl alcohol.

Tables 1 and 2 show recent data on total airborne particulate and solvent pollution obtained from area samplers. In all the measurements benzene seemed to be far below $1 \mathrm{mg} / \mathrm{m}^{3}$ or even absent.

\section{Investigated subjects}

The total population of the workers of the factory amounts to 1096 white men subdivided into various departments as follows: $4.5 \%$ in mixing and compounding areas, $26.5 \%$ in extruding and calendering, $20 \%$ in tyre building, $4.5 \%$ in tyre vulcanisation, $5.4 \%$ in inner tube manufacturing, and $39.1 \%$ in other departments: 121 clerks are employed in the administrative department of the factory. Table 3 shows the main characteristics (job category, smoking habits, etc) of the investigated workers and clerks.

Table 1 Total airborne particulate $\left(\mathrm{mg} / \mathrm{m}^{3}\right)$ in various departments

\begin{tabular}{ll}
\hline Department & Average value $\pm S D$ \\
\hline Mixing & $0.70 \pm 0.33$ \\
Weighing & $2.73 \pm 1.66$ \\
Compounding & $0.93 \pm 0.37$ \\
Extruding & $1.03 \pm 0.89$ \\
Calendering & $0.37 \pm 0.10$ \\
Tyre building & $0.36 \pm 0.08$ \\
Vulcanising & $1.11 \pm 1.06$ \\
Talc area & $2.17 \pm 1.64$ \\
\hline $\mathrm{n}=4$. &
\end{tabular}

\section{Urinary mutagenicity assays}

Urine samples were collected on Thursday afternoon at the end of the workshift from 72 workmen (44 smokers) and 23 control clerks (16 smokers). After collection the urines were quickly frozen and stored in the dark at $-20^{\circ} \mathrm{C}$. Precautions were taken to avoid any chemical contamination during collection and storage. Urine concentrates were prepared by absorption on to XAD- 2 resin as described by Yamasaki and Ames $^{6}$ after overnight incubation with $100 \mathrm{u} / \mathrm{ml}$ Escherichia coli $\beta$-glucuronidase

Table 2 Solvent pollution $\left(\mathrm{mg} / \mathrm{m}^{3}\right)$ in various departments

\begin{tabular}{|c|c|c|c|c|}
\hline \multirow[t]{2}{*}{ Department } & \multicolumn{4}{|l|}{ Solvent } \\
\hline & Technical heptane & Hysopropylic alcohol & Naptha & Ethyl alcohol \\
\hline $\begin{array}{l}\text { Rubber starch and solvent } \\
\text { compounding } \\
\text { Agricultural tyre building } \\
\text { Passenger tyre building } \\
\text { Tyre painting }\end{array}$ & $\begin{array}{r}1626 \pm 2600 \\
329 \pm 365 \\
99 \pm 87 \\
218 \pm 293\end{array}$ & $\begin{array}{l}\frac{13}{-} \pm 11 \cdot 5 \\
3 \cdot 2 \pm 1 \cdot 8\end{array}$ & $\begin{array}{l}735 \pm 341 \\
=\end{array}$ & $\begin{array}{l}42 \pm 48 \\
- \\
-\end{array}$ \\
\hline
\end{tabular}


Table 3 Main characteristics of the investigated workers and control group

\begin{tabular}{lcccccc}
\hline Job & $\begin{array}{l}\text { No of } \\
\text { subjects } \\
\text { investigated }\end{array}$ & $\begin{array}{l}\text { \% of } \\
\text { handforce* }\end{array}$ & $\begin{array}{l}\text { Average age } \\
\text { (years) }\end{array}$ & $\begin{array}{l}\text { Average duration } \\
\text { of employment in } \\
\text { factory (years) }\end{array}$ & $\begin{array}{l}\text { No of } \\
\text { smokers }\end{array}$ & Main exposure \\
\hline $\begin{array}{l}\text { Chemical weighers } \\
\text { Banbury mixers and } \\
\text { calenderers }\end{array}$ & 6 & 100 & 40 & 7 & 6 & Rubber chemicals dust \\
$\begin{array}{l}\text { Rubber starch and solvent } \\
\text { compounding workers }\end{array}$ & 16 & 20 & 42 & 8 & 6 & Fumes of uncured rubber \\
$\begin{array}{l}\text { Tyre builders } \\
\begin{array}{l}\text { Vulcanisers } \\
\text { Control clerks }\end{array}\end{array} \quad 22$ & 100 & 44 & 12 & 2 & $\begin{array}{l}\text { Solvents, carbon black } \\
\text { Skin contact with uncured } \\
\text { rubber and solvents }\end{array}$ \\
\hline
\end{tabular}

*Referred to single jobs.

(type VII, Sigma Chemical Co). Amounts of concentrates equivalent to $10 \mathrm{ml}$ of urine were assayed in both the Salmonella plate incorporation assay (Ames test) and the microtitre fluctuation test ${ }^{78}$ car- $^{-}$ ried out with strains TA1535, TA98, and TA100 in the presence of postmitochondrial fractions (S9) from Aroclor 1254 (Monsanto) induced male Sprague-Dawley rats. 2-Aminoanthracene was used as the positive control. The results were statistically evaluated by the methods of Gilbert" (microtitre fluctuation test) and Mahon $^{10}$ (plate incorporation assay).

\section{RUBBER CHEMICALS STUDY}

Mutagenicity assays

All the bacterial strains used in this work were a kind gift of Professor BN Ames, University of Berkeley, California. The raw materials under test were assayed in the plate incorporation assay ${ }^{7}$ with the $S$ typhimurium strains TA1535, TA1537, TA98, and TA100 in the presence of S9 from Aroclor induced male Sprague-Dawley rats. Each of the chemicals was assayed in a range of concentrations up to the maximum tolerated dose. Each determination was made in triplicate and repeated at least once. The chemicals which resulted in a mutagenic event - that is, by inducing reproducible dose related increases in the number of his $^{+}$revertants ${ }^{11}$ - were also tested in the absence of $S 9$ to clarify the possible dependence of their activity on the presence of the exogenous metabolic system. 2-Aminoanthracene, sodium azide, and 4-nitro-o-phenylendiamine were used as positive controls. S9 fractions and chemical samples were routinely checked for sterility. Dimethylsulphoxide (Carlo Erba, 99.5\%) was used as solvent for all the chemicals with the exception of cobalt naphthenate which was dissolved in $\mathrm{NaOH}(0 \cdot 1 \mathrm{~N})$.

\section{Chemicals}

All the chemicals were technical grade products obtained from the chemical laboratory of the factory. Table 4 shows the chemical names, CAS numbers, purity, and classes of use.

\section{Results}

\section{URINARY MUTAGENICITY STUDY}

Figure 1 shows the results obtained by assaying amounts of urine concentrates equivalent to $10 \mathrm{ml}$ of urine in the microtitre fluctuation test. The activity of the positive samples was roughly evaluated on the basis of the level of statistical significance of the response obtained. A comparison of the frequencies of mutagenic samples among all the exposed workers and control clerks in strains TA1535, TA98, and TA100 did not show any significant excess of positive samples among the former (Fisher test); the same comparison between workmen and control clerks, taking into account single job categories and their smoking habits, also failed to show any significant prevalence of mutagenic samples among the employees.

On the other hand, when all the smokers (both workmen and clerks) were compared with nonsmokers, a highly significant excess of mutagenic samples was observed among smokers (strain TA98, $30 / 56 v 3 / 34, \mathrm{p}<0.001)$. A possible synergistic effect of occupation with smoking was suggested by the prevalence of samples with high mutagenic activity (positive responses with $p<0.001$, in fig 1) among workmen who smoked as compared with smoking controls (strain TA98, 9/40 v 1/16); this difference did not reach statistical significance $(p=$ $0 \cdot 10$ ) but showed a trend toward synergism.

A similar picture appears when evaluating the results obtained from the Ames test. Figure 2 shows the relative frequencies of positive results obtained by assaying urine concentrates of the investigated subjects in the plate incorporation assay. With this test only weak mutagenic activities were observed and therefore only one level of statistical significance was considered $(p<0.05)$. No 
Table 4 Rubber chemicals screening: results in the Salmonella reversion assay

\begin{tabular}{|c|c|c|c|c|}
\hline Chemical name (CAS No) & Purity & Use class & $\begin{array}{l}\text { Range of } \\
\text { concentration } \\
\text { ( } \mu \text { g/plate) }\end{array}$ & Activity \\
\hline $\begin{array}{l}\text { N,N'-dimethylpenthyl-p-phenylendiamine (3081-14-9) } \\
\text { Diaryl-p-phenylendiamines mixed } \\
\text { N-isopropyl-N'-phenyl-p-phenylendiamine (101-72-4) } \\
\text { Pentachlorothiophenol (117-95-5) } \\
\text { 1,3-Diphenylguanidine (102-06-7) } \\
\text { 4-Morpholinyl-2-benzothiazyl disulphide }(95-32-9) \\
\text { N-oxydiethylene-2-benzothiazolesulphenamide }\end{array}$ & $\begin{array}{l}\text { Unknown } \\
80 \% \\
95 \% \\
47 \% \\
96.5 \% \\
94 \%\end{array}$ & $\begin{array}{l}\text { Antioxidant } \\
\text { Antioxidant } \\
\text { Antioxidant } \\
\text { Peptiser } \\
\text { Accelerator } \\
\text { Accelerator }\end{array}$ & $\begin{array}{c}200-5000 \\
200-5000 \\
20-500 \\
40-1000 \\
200-5000 \\
40-200\end{array}$ & $\begin{array}{l}\text { Negative } \\
\text { Positive in TA98 } \\
\text { Negative } \\
\text { Negative } \\
\text { Negative } \\
\text { Negative }\end{array}$ \\
\hline $\begin{array}{l}\text { Poly (trimethyl-dihydroquinoline) }(26780-96-1) \\
\mathrm{N} \text { (cyclohexylthio)phtalimide }(17796-82-6) \\
\mathrm{N}, \mathrm{N}-\text { diisopropyl-2-benzothiazolesulphenamide }\end{array}$ & $\begin{array}{l}\text { Unknown } \\
\text { Unknown } \\
\text { Unknown }\end{array}$ & $\begin{array}{l}\text { Accelerator } \\
\text { Antioxidant } \\
\text { Retarder }\end{array}$ & $\begin{array}{c}10-1000 \\
40-1000 \\
2 \cdot 5-40\end{array}$ & $\begin{array}{l}\text { Negative } \\
\text { Negative } \\
\text { Negative }\end{array}$ \\
\hline $\begin{array}{l}\text { (95-29-4) } \\
\text { Hexamethylenetetramine }(100-97-0) \\
\text { Resorcinol }(108-46-3) \\
\text { Popy-p-dinitrosobenzene }(9003-34-3) \\
\text { Tetramethyltiuram disulphide }(137-26-8)\end{array}$ & $\begin{array}{l}98.5 \% \\
\text { Unknown } \\
99 \% \\
25 \% \\
\text { Unknown }\end{array}$ & $\begin{array}{l}\text { Accelerator } \\
\text { Accelerator } \\
\text { Bonding } \\
\text { Accelerator } \\
\text { Accelerator }\end{array}$ & $\begin{array}{l}10-200 \\
200-5000 \\
200-5000 \\
8-200 \\
8-200\end{array}$ & $\begin{array}{l}\text { Negative } \\
\text { Negative } \\
\text { Negative } \\
\text { Positive in TA98 } \\
\text { Positive in TA98 } \\
\quad \text { and TA100 }\end{array}$ \\
\hline $\begin{array}{l}\text { Phenol-formaldehyde resin (9003-35-4) } \\
\text { Stearic acid }(57-11-4) \\
\text { Zinc oxide }(1314-13-2) \\
\text { Sulphur (7704-34-9) } \\
\text { Sulphur mixed with mineral oil } \\
\text { 2,2'-Dithio-bis(benzothiazole) (120-78-5) } \\
\text { 2-Mercaptobenzothiazole (149-30-4) } \\
\text { Cobalt napthenate }\end{array}$ & $\begin{array}{l}\text { Unknown } \\
\text { Unknown } \\
99 \%\end{array}$ & $\begin{array}{l}\text { Softener } \\
\text { Softener } \\
\text { Activator } \\
\text { Accelerator } \\
\text { Accelerator } \\
\text { Accelerator } \\
\text { Accelerator } \\
\text { Bonding agent }\end{array}$ & $\begin{array}{r}200-5000 \\
40-1000 \\
1000-5000 \\
1000-3000 \\
1000-3000 \\
40-1000 \\
8-200 \\
500-2500\end{array}$ & $\begin{array}{l}\text { Negative } \\
\text { Negative } \\
\text { Negative } \\
\text { Negative } \\
\text { Negative } \\
\text { Negative } \\
\text { Negative } \\
\text { Negative }\end{array}$ \\
\hline
\end{tabular}

*A mixture of $\mathrm{N}, \mathrm{N}^{\prime}$-diphenyl-p-phenylendiamine, $\mathrm{N}, \mathrm{N}^{\prime}$-di-o-tolyl-p-phenylendiamine, $\mathrm{N}$-phenyl- $\mathrm{N}^{\prime}$-o-tolyl-p-phenylendiamine, and diphenylamine in proportions protected by industrial secret.

Spontaneous control values $(\bar{x} \pm$ SD) were: TA1535 with S9, $14 \pm 4(n=24)$; TA1537 with $S 9,12 \pm 4(n=15)$; TA98 without $S 9,38 \pm$ $9(n=9)$; TA98 with $S 9,32 \pm 10(n=25)$; TA100 without $S 9,200 \pm 29(n=9) ;$ TA100 with $S 9,153 \pm 41(n=27)$. Activity of positive controls was as follows: $1 \mu \mathrm{g}$ of 2-aminoanthracene induced, in presence of S9, $145 \pm 60$ revertants in TA1535 (n=15); $169 \pm 57$ in TA1537 $(\mathrm{n}=12) ; 690 \pm 215$ in TA98 $(\mathrm{n}=24) ; 749 \pm 226$ in TA100 $(\mathrm{n}=21)$. In absence of $S 9,5 \mu \mathrm{g} 4$-nitro-o-phenylendiamine induced $605 \pm 156$ revertants in TA98 $(n=12) ; 5 \mu \mathrm{g}$ sodium azide $739 \pm 416$ in TA100 $(n=9)$. Other data on activity of rubber chemicals are available on request.

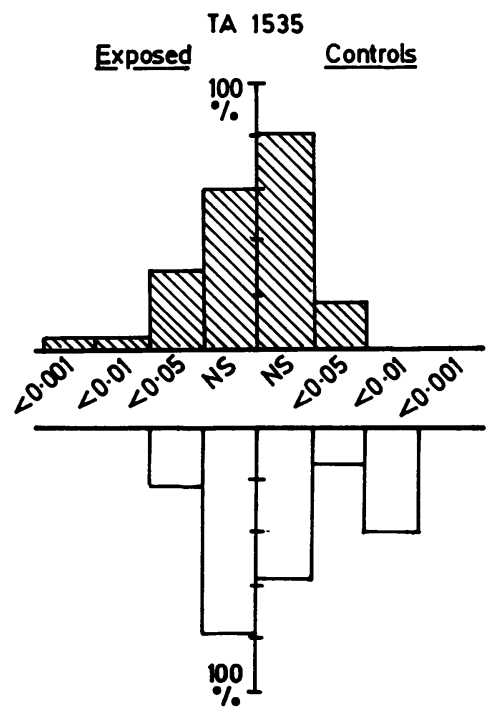

Exposed smokers $n 40$ Control smokers in 16
TA 100

Exposed

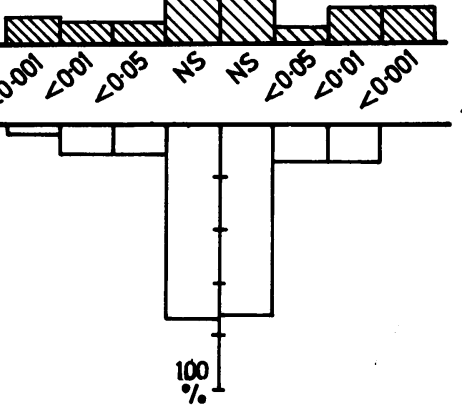

Smokers

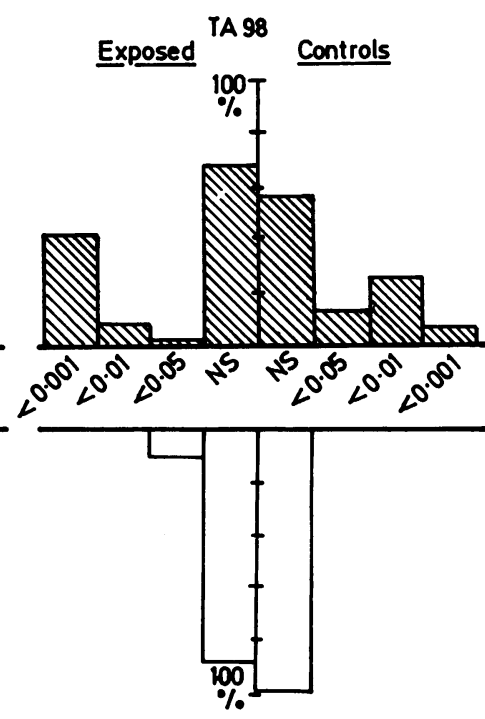

Non-smoker

Fig 1 Mutagenic activity of urinary concentrates in microtitre fuctuation test. Percent of concentrates which gave negative (NS) or positive results at different levels of significance is shown. Spontaneous control values $(\bar{x} \pm S D, 12$ experiments) were: TA1535, $2.4 \pm 1.7$ positive wells out of $96 ;$ TA98, $5.5 \pm 3 \cdot 3 ;$ TA100, $17.7 \pm 7 \cdot 1$. Numbers of positive wells in presence of $0 \cdot 2 \mu \mathrm{g} / \mathrm{ml}$ of 2-aminoanthracene were: TA1535, $68 \cdot 7 \pm 17 \cdot 7 ;$ TA98; $88 \cdot 8 \pm 9 \cdot 7 ;$ TA100 78.9 $\pm 10 \cdot 8$. 


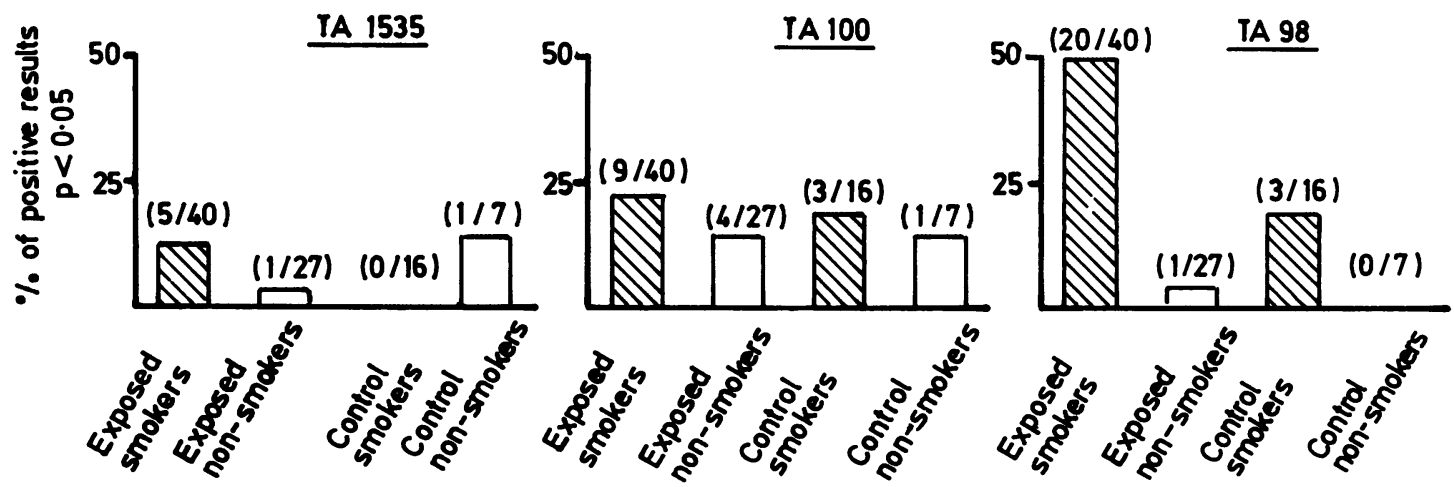

Fig 2 Mutagenic activity of urinary concentrates in plate incorporation assay (Ames test). Percent of urine concentrates which gave positive results at $p<0.05$ is shown. Spontaneous control values were: TA1535, $12 \pm 4$ ( $n=23), T A 98,36 \pm$ $9(n=27), T A 100,150 \pm 46(n=27) .2$-Aminoanthracene $(0.8 \mu \mathrm{g} /$ plate $)$ induced $88 \pm 35$ revertants in TA1535 $(n=$ 22); $552 \pm 210$ in TA98 $(n=27) ; 607 \pm 131$ in $T A 100(n=27)$.

significant difference in the frequency of mutagenic samples was found comparing unexposed and exposed employees. An excess of mutagenic samples were observed, however, among workmen who smoked by comparison with clerks who smoked (strain TA98, 20/40 v 3/16); this prevalence did not reach statistical significance $(p=0 \cdot 07)$. A significant difference was observed when the comparison was made between tyre builders who smoked and smoking clerks $(8 / 11 \vee 3 / 16, p<0.01)$. Finally, as described by others, ${ }^{61213}$ a highly significant excess of mutagenic urine concentrates was observed in smokers when they were compared with nonsmokers (strain TA98, 23/56 v 1/34, p < 0.001).

\section{RUBBER CHEMICALS STUDY}

The results obtained by assaying the rubber chemicals in the Salmonella/microsome assay are briefly summarised in table 4 . Most of the chemicals did not induce any reproducible increase in the number of $\mathrm{his}^{+}$revertants in the range of concentrations assayed and were therefore evaluated as negative-that is, non-mutagenic. Three of the materials on the other hand turned out to be positive, increasing the number of his $^{+}$revertants in a dose related manner. Tetramethyltiuram disulphide (TMTD) was active in strain TA98, which is suitable for the detection of frame shift mutagens and in TA100, which detects mutagens inducing base pair substitutions through an error prone cellular response ${ }^{14}$; poly-p-dinitrosobenzene and mixed diaryl-p-phenylendiamines were only active toward TA98 (fig 3). These chemicals were also assayed in the absence of $\mathbf{S} 9$ fractions as exogenous activating system. The results in fig 3 show that poly-pdinitrosobenzene retained its activity unchanged in the absence of S9, whereas TMTD and the mixed diaryl-p-phenylendiamines were ineffective as mutagens under these conditions.

\section{Discussion}

Three main conclusions may be drawn from the results described in this paper: (a) occupational exposure to xenobiotics is not detectable as urinary mutagenicity in the rubber workers investigated; $(b)$ smoking habits are strongly related to the appearance of urinary mutagens detectable with strain TA98; (c) a minor fraction (3/22) of the raw materials in use in the workplace investigated is weakly mutagenic in the Salmonella reversion system.

Similar investigations have been carried out by others in rubber industries in northern Europe. These studies showed a significant increase in urinary mutagenicitys or cytogenetic damage in the peripheral lymphocytes in exposed workers. ${ }^{15}$ These results do not agree with those described in this paper nor with those of a cytogenetic study concurrently carried out on a group of vulcanisers of the same plant. ${ }^{16}$ An explanation for these discrepancies might lie in the different individual exposure to genotoxic xenobiotics in the workplaces investigated. In fact the genotoxic hazard is not an unavoidable feature of the rubber industry: the improvement of industrial hygiene, either by improvements in process equipment or proper selection of raw materials, can effectively reduce exposure to genotoxic chemicals. In the workplace investigated by us only three of the major chemicals in use were endowed with a low mutagenic activity, far below that exerted by tobacco tar. Although the low 

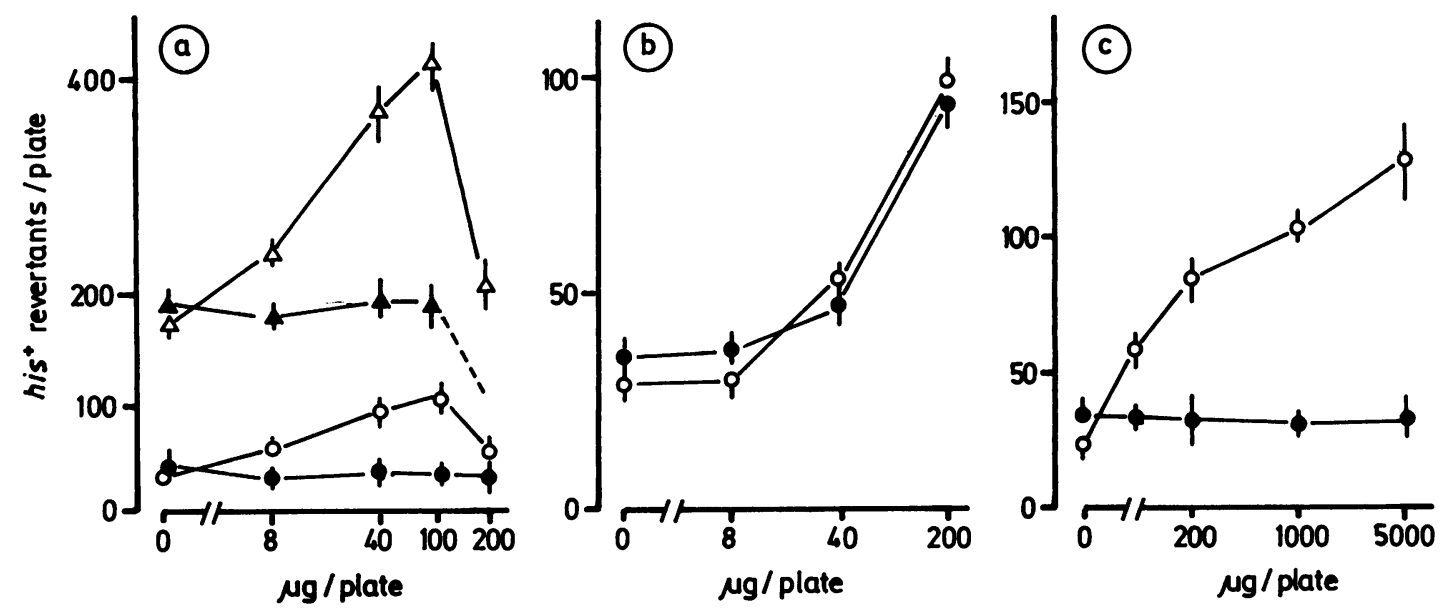

Fig 3 Mutagenicity of technical grade rubber chemicals in plate incorporation assay: (a) tetramethyltiuram disulphide, (b) poly-p-dinitrosobenzene, (c) mixed diaryl-p-phenylendiamines. Open symbols: with S9. Closed symbols: without S9. Circles: TA98. Triangles: TA100.

in vitro mutagenicity of these raw materials cannot be quantitatively related to their possible carcinogenic potency, ${ }^{17}$ it should be considered when evaluating the results of the urinary monitoring. It has in fact been shown that $1 \mathrm{mg}$ of cigarette tar is able to induce about 1000 revertants in the Salmonella test system. ${ }^{18}$ Considering that a cigarette smoker (one pack a day) inhales about $500 \mathrm{mg}$ of tar each day, ${ }^{18}$ the intake of mutagens by tobacco smoke is probably far above the intake of bacterial mutagens possibly related to the occupation.

In any event, the absence of a detectable urinary mutagenicity in the rubber workers investigated is not proof of no exposure to genotoxic agents. The recovery of mutagenic metabolites of genotoxic chemicals in urine is dependent, apart from the extent and route of exposure, on the metabolic and pharmacokinetic characteristics of each chemical. Therefore a negative result does not allow one to rule out the possibility of a limited exposure to genotoxic chemicals. It simply indicates that the previous exposure was below the lowest detectable level. In this connection the possible occupational exposure to volatile nitrosamine should not be disregarded: it has been shown that carcinogenic nitrosamines have a widespread occurrence in the workroom air in the rubber industry ${ }^{19}$ and that the exposure to nitrosamines is not effectively detected by the urinary mutagenicity study. ${ }^{20}$

The last point concerns the possible synergistic effect between smoking habits and occupation. This effect was indicated by the prevalence of mutagenic urinary concentrates among workmen who smoke by comparison with smoking clerks. The biological meaning and health implications of this effect, which has already been described by others, ${ }^{3}$ are at present unknown. Epidemiological studies, however, suggest that the combination of different chemical exposures could be more relevant than single causative agents in the aetiology of occupational cancer in the rubber industry.' According to this view tobacco smoke could act synergistically with the occupational exposure to xenobiotics by increasing the variety of possible chemical interactions. Furthermore the enzymatic induction that occurs in cigarette smokers $^{21}$ could be responsible for the increased urinary excretion of mutagens in exposed workers who smoke. It has been shown that pretreatment with enzyme inducers can increase the urinary excretion of mutagens in mice that have been administered carcinogens. ${ }^{22}$

The technical help of Mrs M C D'Ascoli, Mrs L Gargano, and Mr U Cervelli is gratefully acknowledged. This work was partially supported by the EEC (contract No 530 ENV I-s).

Parts of these data were presented at the International Seminar on Methods of Monitoring Human Exposure to Carcinogenic and Mutagenic Agents, 12-15 December 1983, Espoo, Finland.

Requests for reprints to: Dr R Crebelli, Laboratorio di Tossicologia Applicata, Istituto Superiore di Sanità, Viale Regina Elena, 299-00161 Rome, Italy. 


\section{References}

' International Agency for Research on Cancer. Monographs on the evaluation of the carcinogenic risk of chemicals to humans. In: The rubber industry. Vol 28. Lyon: IARC, 1982.

${ }^{2}$ Vainio H, Savolainen H, Kilpikari I. Urinary thioethers of employees of a chemical plant, $\mathrm{Br} J$ Ind Med 1978;35:232-4.

${ }^{3}$ Falck K, Sorsa M, Vainio H. Mutagenicity in urine of workers in rubber industry. Mutat Res 1980;79:45-52.

${ }^{4}$ Kilpikari I. Correlation of urinary thioethers with chemical exposure in a rubber plant. Br J Ind Med 1981;38:98-100.

${ }^{5}$ Vainio H, Falck K, Madi-Pakkanen J, Sorsa M. Possibilities for identifying genotoxic risks in the rubber industry: use of the urinary mutagenicity assay and sister chromatid exchange. In: Host factors in human carcinogenesis. Lyon: International Agency for Research on Cancer, 1982:571-7. (IARC scientific publications No 39.)

- Yamasaki E, Ames BN. Concentration of mutagens from urine by absorption with the nonpolar resin XAD-2: cigarette smokers have mutagenic urine. Proc Natl Acad Sci USA 1977;74:3555-9.

' Ames BN, McCann J, Yamasaki E. Methods for detecting carcinogens and mutagens with the Salmonella/mammalian microsome mutagenicity test. Mutat Res 1975;31:347-64.

${ }^{8}$ Gatehouse DH, Delow GF. The development of a "microtitre" fluctuation test for the detection of indirect mutagens, and its use in the evaluation of mixed enzyme induction of the liver. Mutat Res 1979;60:239-52.

' Gilbert RI. The analysis of fluctuation test. Mutat Res 1980;74:283-9.

${ }^{10}$ Mahon GAT. The statistical significance of the Ames test results. In: Genetic effects of environmental chemicals: progress reports presented at the 12th meeting of the contact group, London, 6-7 January, 1983. EEC Environmental Research Program. Doc XII/1170/82-EN. 109-15.

" de Serres FJ, Shelby MD. The Salmonella mutagenicity assay: recommendations. Science 1979;203:563-5.

12 van Doorn R, Bos RP, Leijdekkers CM, Wagenaas-Zegers MAP, Theuws JLC, Henderson PT. Thioether concentration and mutagenicity of urine from cigarette smokers. Int Arch Occup Environ Health 1979;43:159-66.

${ }^{13}$ Putzrath RM, Langley D, Eisenstdt E. Analysis of mutagenic activity in cigarette smokers' urine by high performance liquid chromatography. Mutat Res 1981;85:97-108.

${ }^{14}$ McCann J, Spingarn NE, Kobori J, Ames BN. The detection of carcinogens as mutagens: bacterial tester strains with $\mathbf{R}$-factor plasmids. Proc Natl Acad Sci USA 1974;72:979-83.

is Sorsa M, Maki-Pakkanen J, Vainio H. Identification of mutagen exposures in the rubber industry by the sister chromatid exchange method. Cytogenet Cell Genet 1982;33:68-73.

${ }^{16}$ Degrassi F, Fabri G, Palitti F, Paoletti A, Ricordy R, Tanzarella C. Biological monitoring of workers in the rubber industry: $\mathbf{I}$. Chromosomal aberrations and sister chromatid exchanges in lymphocytes of vulcanizers. Mutat Res 1984;138:99-103.

17 Ashby J, Styles JA. Does carcinogenic potency correlate with mutagenic potency in the Ames assay? Nature 1979; 271:452-5.

${ }^{18} \mathrm{Kier}$ LD, Yamasaki E, Ames BN. Detection of mutagenic activity in cigarette smoke condensates. Proc Natl Acad Sci USA 1974;71:4159-63.

${ }^{14}$ Spiegelhalder B. Carcinogens in the workroom air in the rubber industry. Scand J Work Environ Health 1983;9, suppl 2:1525.

21" Ohshima H, Bereziat JC, Bartsch H. Measurement of endogenous $\mathrm{N}$-nitrosation in rats and humans by monitoring urinary and faecal excretion of $\mathrm{N}$-nitrosamino acids. In: $\mathrm{N}$-nitroso compounds: occurrence and biological effects. Lyon: International Agency for Research on Cancer, 1982:397-411. (IARC scientific publications No 41.)

${ }^{21}$ Conney AH. Induction of microsomal enzymes by foreign chemicals and carcinogenesis by polycyclic aromatic hydrocarbons: GHA Clowes memorial lecture. Cancer Res 1982;42:4875917.

${ }^{22}$ Camus A-M, Aitio A, Sabadie N, Wahrendorf J, Bartsch H. Metabolism and urinary excretion of mutagenic metabolites of benzo(a)pyrene in C57 and DBA mice strains. Carcinogenesis 1984;5:35-9.

\section{Vancouver style}

All manuscripts submitted to the $B r J$ Ind Med should conform to the uniform requirements for manuscripts submitted to biomedical journals (known as the Vancouver style).

The Br J Ind Med, together with many other international biomedical journals, has agreed to accept articles prepared in accordance with the Vancouver style. The style (described in full in $\mathrm{Br}$ Med J, 24 February 1979, p 532) is intended to standardise requirements for authors.

References should be numbered consecutively in the order in which they are first mentioned in the text by Arabic numerals above the line on each occasion the reference is cited (Manson' confirmed other reports ${ }^{2-5} \ldots$..). In future references to papers submitted to the $\mathrm{Br} J$ Ind Med should include: the names of all authors if there are six or less or, if there are more, the first three followed by et al; the title of journal articles or book chapters; the titles of journals abbreviated according to the style of Index Medicus; and the first and final page numbers of the article or chapter.

Examples of common forms of references are:

' International Steering Committee of Medical Editors. Uniform requirements for manuscripts submitted to biomedical journals. Br Med J 1979; 1:532-5.

${ }^{2}$ Soter NA, Wasserman SI, Austen KF. Cold urticaria: release into the circulation of histamine and eosinophil chemotactic factor of anaphylaxis during cold challenge. $N$ Engl J Med 1976;294:687-90.

${ }^{3}$ Weinstein L, Swartz MN. Pathogenic properties of invading micro-organisms. In: Sodeman WA Jr. Sodeman WA, eds. Pathologic physiology: mechanisms of disease. Philadelphia: W B Saunders, 1974:457-72. 